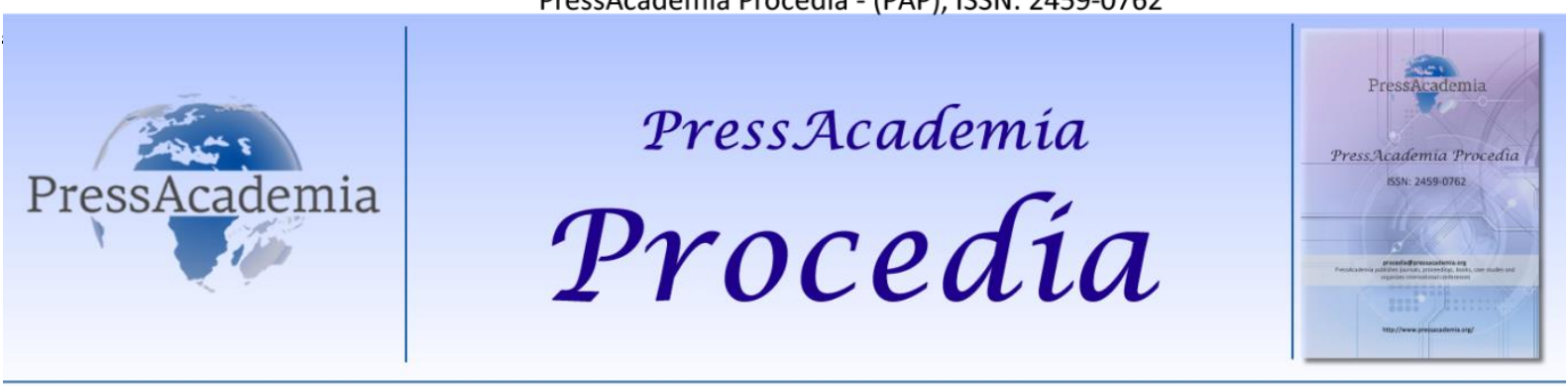

2nd World Conference on Technology, Innovation and Entrepreneurship

May 12-14, 2017, Istanbul, Turkey. Edited by Sefer Şener

\title{
ANALYSIING THE ENTREPRENEURSHIP PERFORMANCE FOR OECD COUNTRIES VIA ENTROPY-MAUT INTEGRATED TECHNIQUE
}

\author{
DOI: 10.17261/Pressacademia.2017.538 \\ PAP-WCTIE-V.4-2017(30)-p.224-230
}

\section{Gizem Sayan Akinci, Ozge Eren}

\begin{abstract}
The purpose of this article is to analyse the entrepreneurship performance for OECD countries based on the OECD data for the years 20142015. The set of entrepreneurship indicators are part of the OECD-Eurostat Entrpreneurship Indicators Program (EIP). EIP develops policyrelevant and internationally comparable indicators based on an analytical model and measurement infrastructure that allows gathering comparable data. The indicators that are used in this model are; employees by business size, enterprises by business size, self-employed with employees, self-employed without employees and starting a business. We measure the entrepreneurship performance of OECD countries by using the Entropy-Maut hybrid model. Entropy method has been used to determine the weights of the above mentioned indicators and also these weights have been used with MAUT (multi-attribute utility theory) to rank entrepreneurship performance which is an important indicator for the economic development. Our aim is to rank groups of countries with similar entrepreneurial indicators and to determine the drivers of entrepreneurship in each group.
\end{abstract}

Keywords: Entrepreneurship, multi attribute utility theory, entropy, Ranking, OECD. JEL Codes: K10

\section{INTRODUCTION}

It is well-known that entrepreneurship and entrepreneurs are important drivers of economic growth,employment, innovation and productivity. Entrepreneurship contributes to output and growth by acting as a conduit for knowledge spillovers, fostering competition through the increased number of enterprises, and by increasing diversity through providing enterprises with various and different activities.(Audretsch, D.B., 2007). It has become widely acknowledged that entrepreneurship is a vital force in the economies of developed countries, (Audretsch, D., Fritsch, M., 2003; Decker, R., et al 2014). The level of entrepreneurship, differs strongly across countries (Van Stel et al 2005). This variation is related to differences in levels of economic development, and as well as diverging demographic, cultural and institutional characteristics (Blanchflower 2000; Wennekers 2006). . In other words: the relative stability of differences in entrepreneurial activity across countries suggests that factors other than economic ones are at play (Grilo and Thurik 2005). Over the decades, researchers have created several entrepreneurship indicators, but none has been able to reflect the complex nature of entrepreneurship. Given its experience in international data development, many countries and groups turned to the OECD for assistance and guidance in developing such a framework for entrepreneurship performance. These initiatives and requests led the OECD to create an Entrepreneurship Indicators Programme (EIP) that seek to improve entrepreneurship indicators. EIP develops policy-relevant and internationally comparable indicators based on an analytical model and measurement infrastructure that allows gathering comparable data.

The purpose of this article is to analyse the entrepreneurship performance for OECD countries based on the OECD data for the years 2014-2015. The set of entrepreneurship indicators are part of the OECD-Eurostat Entrepreneurship Indicators Program (EIP). The indicators that are used in this model are; employees by business size, enterprises by business size, selfemployed with employees, self-employed without employees and starting a business. Employees by business size is measured as the number of employees in manufacturing. Enterprises can be classified in different categories according to their size; for this purpose, different criteria may be used, but the most common is number of people employed. In small and medium-sized enterprises (SMEs) employ fewer than 250 people. SMEs are further subdivided into micro enterprises (fewer than 10 employees), small enterprises (10 to 49 employees), medium-sized enterprises (50 to 249 employees). Large enterprises employ 250 or more people. Those who are self-employed with employees are people whose primary activity is 
self-employment and who employ others. Those who are self-employed without employees are people whose primary activity is self-employment and do not employ others. Starting a business covers two factors which are important when starting a business: Access to training on how to start a business shows the percentage of women and of men declaring that they have access to training on how to start or grow a business. Access to money to start a business is the percentage of women and of men declaring that they have access to money to start or grow a business. Our aim is to rank groups of countries with similar entrepreneurial indicators and to determine the drivers of entrepreneurship in each group.

\section{LITERATURE REVIEW}

Entrepreneurship is considered to be an important mechanism for economic development through employment, innovation and welfare effects. The simplest kind of entrepreneurship is self-employment. After the mid-1970s, the selfemployment rate started to rise in most modern economies. Blau (1987) observes that, while the proportion of selfemployed started increasing in the early 1970s and then rose until at least 1982. Acs et al. (1994) comments that out of 23 OECD countries, 15 experienced an increase in the self-employment rate during the $1980 \mathrm{~s}$

Some studies have found a positive relationship between entrepreneurship and economic growth (Audretsch, D.B., 2007; Vázquez, E., et al 2010; Salman, D.M. and Badr, K., 2011), while other studies have argued that entrepreneurship impact on economic growth would be undefined. It was found that the impact of entrepreneurship on the economic growth depends on the stage (the level of economic development and many other factors). (Audretsch and Fritsch 2002; Van Stel, et al, 2005; Wennekers et al 2005)

The level of development is also important regarding the entrepreneurial intensity. GEM studies gather countries according to their main engine for growth: factor-driven economies for the less developed ones, efficiency driven economies for the middle class and innovation-driven economies for the more developed ones. It is well-known that the level of entrepreneurship, relative to the labor force, differs strongly across countries (Van Stel, et.al 2005). This situation is related to differences in levels of economic development, and also to diverging demographic, cultural and institutional characteristics (Blanchflower 2000; Wennekers 2006).

There is evidence of a U-shaped relationship between the self employment and per capita income. In other words, while per capita income and technological developments can be attributed to economic development, differences related with cultural and institutional characteristics are at play. (Grilo and Thurik 2005, Grilo and Irigoyen 2006)

Van Stel et al. (2007) examine the relationship between regulation and entrepreneurship in 39 countries and show that the minimum capital requirement for starting a business decreases entrepreneurship rates across countries, while administrative procedures such as time, the cost or the number of procedures needed to start a business do not. If the cost of starting a new firm is low, the employee may decide to establish a new enterprise.

EU countries have been compared with respect to the ease of starting a business. Countries such as Germany, Austria and Malta show considerable room for improvement, while the western EU countries have high overall scores on this measure. Apart from Poland and the Czech Republic, this is also the case for the Eastern European countries. (Elert, et al. 2017)

\section{METHODOLOGY}

In this study, the methods of Entrophy\&Maut integrated forms are used. These methods are acceptable for doing fair classification for the indicators of Entrepreneurship. Multi-Criteria Decision Analysis (MCDA) have a widespread applications area in the world and lately it can be seen at integrated form (Ahp- Topsis ; Ahp -Maut; Entrophy-Maut....etc).

\subsection{Entropy}

One of the main important objective weighting measure is the Shannon entropy concept. Firstly, it has been defined by Rudolph Clausius (1865) as a measure of uncertainty and irregularity in the system (Zhang, 2011). Firstly, it was widely used primarily in physics area but today including mathematics and engineering sciences also social sciences it has been using with the different applications. Entropy Weight method is used to measure the amount of useful information provided by the available data (Wu, 2011). In social sciences, It is seen this method is often preferred to determine the index weight. The following steps are shown below:

Step 1: Set the the evaluation matrix (with the dimension $m \times n$ ) 


$$
A_{i j}=\left[\begin{array}{cccc}
x_{11} & x_{12} & \ldots & x_{1 n} \\
x_{21} & x_{22} & \ldots & x_{2 n} \\
\cdot & & & \cdot \\
\cdot & & & \cdot \\
\cdot & & & \cdot \\
x_{m 1} & x_{m 2} & \ldots & x_{m n}
\end{array}\right]
$$

Step 2: Standardized each criteria with the help of equations represented by following equality.

$$
\begin{gathered}
r_{i j}=\frac{x_{i j}}{\operatorname{mak}_{i j}}(i=1,2,3 \ldots . m ; j=1,2, \ldots \ldots \ldots n) \\
r_{i j}=\frac{\min _{i j}}{x_{i j}}(i=1,2,3 \ldots . m ; j=1,2, \ldots \ldots \ldots n)
\end{gathered}
$$

Step 3: Determine all index values's entropy

$$
\begin{gathered}
e_{j}=-\frac{\sum_{i=1}^{m} f_{i j} \ln f_{i j}}{\ln m} \quad(i=1,2 \ldots m ; j=1,2 \ldots \ldots n) \\
f_{i j}=\frac{r_{i j}}{\sum_{i=1}^{m} r_{i j}}(i=1,2 \ldots m ; j=1,2 \ldots \ldots n) \\
W_{j}=\frac{1-e_{j}}{n-\sum_{i=1}^{m} e_{j}} \text { and } \sum_{j=1}^{n} W_{j}=1 \quad(j=1,2 \ldots \ldots, n)
\end{gathered}
$$

\subsection{Maut (Multi Attribute Utility Theory):}

Multi Attribute Utility Theory takes into account the preferences in the form of the utility function which is indicated over a set of attribute (Pohekar, Ramachandran, 2004). The utility function sets preferences by assigning a numerical index to different levels of any criterion (Mustafa, Ryan, 1990). For a single criterion ( $\mathrm{x}$ ), the utility of satisfaction of a consequence $\mathrm{x}^{\prime}$ is denoted by $u\left(x^{\prime}\right)$. The utility is measured as the sum of the marginal utilities (Figueira, Greco, Ehrgott, 2005). This method includes both multi-attribute decision-making for discrete decision problems and multi-objective decision-making for continuous problems. In this study, It has been preferred to study for discrete type. The most common method of multicriteria utility function of the discrete decision is the additive model (Keeney, Raiffa, 1993).

$$
U_{i}=\sum_{j=1}^{m} w_{j} U_{i j} \text { for all } i
$$

$U_{i}=$ Total utility value for all of alternative of " $i$ "

$U_{i j}=$ Utility value for the alternative of $i$ (criteria for the $\mathrm{j}$ )

$n=$ Number of criteria

$m=$ Number of alternatives

MAUT method includes six important steps;

Step 1: Set the criteria $\left(C_{1}, C_{2}, \ldots \ldots . C_{n}\right)$ and alternatives

Step 2: Calculate weighted values (with entropy) 
Step 3: Set the the decision matrix

$$
\sum_{i=1}^{m} w_{j}=1
$$

Step 4: Calculate the normalized utility values;

$u_{i}\left(x_{i}\right)=\frac{x-x_{i}^{-}}{x_{i}^{+}-x_{i}^{-}} \quad$ (for criteria to be maximized)

$u_{i}\left(x_{i}\right)=\frac{x_{i}^{+}-x}{x_{i}^{+}-x_{i}^{-}}($for the criteria to be minimized $)$

$$
\begin{gathered}
x_{i}^{+}=\text {the best value of the alternatives } \\
x_{i}^{+}=\text {the worst value of the alternatives }
\end{gathered}
$$

Step 5: Calculate total utility

$$
U_{i}=\sum_{j=1}^{m} w_{j} U_{i j} \text { for all } i
$$

Step 6: Rank the alternatives, choose an alternative which has got the most utility.

Table 1: Main and sub-indicators

\begin{tabular}{|l|l|c|}
\hline Main Indicators & Sub-indicators & Indicator Abb. \\
\hline \multirow{3}{*}{ Starting a business } & Access to training men & $\mathrm{I}_{1}$ \\
\cline { 2 - 3 } & Access to training women & $\mathrm{I}_{2}$ \\
\hline \multirow{3}{*}{ Self employed without employees } & Men & $\mathrm{I}_{3}$ \\
\hline \multirow{3}{*}{ Self employed with employees } & Women & $\mathrm{I}_{4}$ \\
\hline \multirow{5}{*}{ Entreprises by business size } & Men & $\mathrm{I}_{5}$ \\
\cline { 2 - 3 } & Women & $\mathrm{I}_{6}$ \\
\hline \multirow{5}{*}{ Employees by business size } & $0-9$ & $\mathrm{I}_{7}$ \\
\cline { 2 - 3 } & $10-19$ & $\mathrm{I}_{8}$ \\
\cline { 2 - 3 } & $20-49$ & $\mathrm{I}_{9}$ \\
\hline & $0-9$ & $\mathrm{I}_{10}$ \\
\cline { 2 - 3 } & $10-19$ & $\mathrm{I}_{11}$ \\
\cline { 2 - 3 } & $20-49$ & $\mathrm{I}_{12}$ \\
\hline
\end{tabular}

Table 2: Raw Data Set

\begin{tabular}{|l|l|l|l|l|l|l|l|l|l|l|l|l|}
\hline & $I_{1}$ & $I_{2}$ & $I_{3}$ & $I_{4}$ & $I_{5}$ & $I_{6}$ & $I_{7}$ & $I_{8}$ & $I_{9}$ & $I_{10}$ & $I_{11}$ & $I_{12}$ \\
\hline AUT & 64,46 & 61,51 & 7,08 & 6,02 & 45,08 & 2,38 & 18576 & 2842 & 2182 & 37753 & 36713 & 66211 \\
\hline BEL & 54,74 & 43,88 & 11,72 & 7,09 & 5,83 & 2,37 & 29944 & 2331 & 1992 & 31654 & 29219 & 63020 \\
\hline CAN & 73,30 & 64,71 & 10,37 & 8,31 & 5,80 & 2,50 & 31670 & 7440 & 6030 & 188278 & 0 & 178264 \\
\hline CZE & 36,83 & 26,12 & 15,46 & 9,58 & 4,72 & 1,79 & 157909 & 4427 & 3866 & 63220 & 55737 & 111107 \\
\hline DNK & 60,29 & 51,75 & 5,64 & 3,14 & 4,87 & 1,69 & 10686 & 1800 & 1374 & 21299 & 23414 & 41678 \\
\hline FIN & 87,49 & 85,11 & 10,70 & 6,45 & 5,98 & 2,05 & 17035 & 1707 & 1279 & 24783 & 22599 & 39286 \\
\hline FRA & 40,08 & 28,04 & 8,04 & 5,15 & 42,92 & 2,17 & 205876 & 12761 & 9554 & 352687 & 200593 & 331465 \\
\hline DEU & 53,89 & 38,27 & 6,05 & 4,40 & 6,10 & 2,39 & 138436 & 37010 & 16420 & 374510 & 505031 & 549519 \\
\hline GRC & 33,18 & 43,06 & 26,71 & 18,21 & 20,67 & 4,33 & 55447 & 1132 & 936 & 85704 & 12653 & 28561 \\
\hline
\end{tabular}




\begin{tabular}{|l|l|l|l|l|l|l|l|l|l|l|l|l|} 
HUN & 36,38 & 36,27 & 5,97 & 42,83 & 22,80 & 3,00 & 40097 & 3131 & 2360 & 62418 & 42196 & 71659 \\
\hline ITA & 43,00 & 46,36 & 18,40 & 12,00 & 7,85 & 32,57 & 328486 & 39402 & 18988 & 472884 & 467354 & 546849 \\
\hline NLD & 58,30 & 47,35 & 12,97 & 9,91 & 5,28 & 2,07 & 53105 & 3382 & 2657 & 67334 & 54519 & 92168 \\
\hline POL & 39,87 & 30,09 & 16,97 & 10,59 & 32,23 & 2,52 & 157056 & 8580 & 7327 & 191564 & 117228 & 217096 \\
\hline PRT & 54,40 & 49,46 & 11,30 & 8,27 & 19,88 & 2,82 & 54420 & 5527 & 3943 & 91572 & 74896 & 120176 \\
\hline & $I_{1}$ & $I_{2}$ & $I_{3}$ & $I_{4}$ & $I_{5}$ & $I_{6}$ & $I_{7}$ & $I_{8}$ & $I_{9}$ & $I_{10}$ & $I_{11}$ & $I_{12}$ \\
\hline SVK & 38,07 & 28,07 & 14,00 & 8,18 & 3,99 & 1,80 & 60348 & 2201 & 1187 & 34543 & 30310 & 36455 \\
\hline ESP & 54,83 & 46,76 & 14,01 & 8,69 & 6,16 & 3,16 & 140164 & 12397 & 9176 & 242480 & 163444 & 276753 \\
\hline SWE & 61,57 & 64,00 & 7,02 & 3,78 & 5,07 & 1,63 & 47482 & 2752 & 2072 & 51538 & 37395 & 63475 \\
\hline TUR & 34,74 & 17,71 & 18,63 & 8,57 & 5,78 & 1,19 & 303590 & 0 & 18076 & 657265 & 0 & 560908 \\
\hline GBR & 54,72 & 50,24 & 14,22 & 8,15 & 43,53 & 1,22 & 95804 & 13081 & 9485 & 221546 & 174793 & 320089 \\
\hline USA & 66,22 & 60,35 & 42,89 & 5,75 & 3,22 & 1,16 & 228477 & 46273 & 37114 & 705930 & 630393 & 1142110 \\
\hline Total & 1046,35 & 919,11 & 278,13 & 195,06 & 297,74 & $\mathbf{7 4 , 7 9}$ & $\mathbf{2 1 7 4 6 0 8}$ & $\mathbf{2 0 8 1 7 6}$ & $\mathbf{1 5 6 0 1 8}$ & $\mathbf{3 9 7 8 9 6 2}$ & $\mathbf{2 6 7 8 4 8 7}$ & $\mathbf{4 8 5 6 8 4 9}$ \\
\hline
\end{tabular}

Table 3: Entropy Weights

\begin{tabular}{|c|c|c|c|c|c|c|c|c|c|c|c|c|}
\hline & $\mathrm{I}_{1}$ & $\mathrm{I}_{2}$ & $\mathrm{I}_{3}$ & $\mathrm{I}_{4}$ & $\mathrm{I}_{5}$ & $I_{6}$ & $\mathrm{I}_{7}$ & $\mathrm{I}_{8}$ & $I_{9}$ & $\mathrm{I}_{10}$ & $\mathrm{I}_{11}$ & $\mathrm{I}_{12}$ \\
\hline & $-0,17$ & $-0,18$ & $-0,09$ & $-0,11$ & $-0,29$ & $-0,11$ & $-0,04$ & $-0,06$ & $-0,06$ & $-0,04$ & $-0,06$ & $-0,06$ \\
\hline AUT & $-0,15$ & $-0,15$ & $-0,13$ & $-0,12$ & $-0,08$ & $-0,11$ & $-0,06$ & $-0,05$ & $-0,06$ & $-0,04$ & $-0,05$ & $-0,06$ \\
\hline BEL & $-0,19$ & $-0,19$ & $-0,12$ & $-0,13$ & $-0,08$ & $-0,11$ & $-0,06$ & $-0,12$ & $-0,13$ & $-0,14$ & 0,00 & $-0,12$ \\
\hline CAN & $-0,12$ & $-0,10$ & $-0,16$ & $-0,15$ & $-0,07$ & $-0,09$ & $-0,19$ & $-0,08$ & $-0,09$ & $-0,07$ & $-0,08$ & $-0,09$ \\
\hline CZE & $-0,16$ & $-0,16$ & $-0,08$ & $-0,07$ & $-0,07$ & $-0,09$ & $-0,03$ & $-0,04$ & $-0,04$ & $-0,03$ & $-0,04$ & $-0,04$ \\
\hline DNK & $-0,21$ & $-0,22$ & $-0,13$ & $-0,11$ & $-0,08$ & $-0,10$ & $-0,04$ & $-0,04$ & $-0,04$ & $-0,03$ & $-0,04$ & $-0,04$ \\
\hline FIN & $-0,12$ & $-0,11$ & $-0,10$ & $-0,10$ & $-0,28$ & $-0,10$ & $-0,22$ & $-0,17$ & $-0,17$ & $-0,21$ & $-0,19$ & $-0,18$ \\
\hline FRA & $-0,15$ & $-0,13$ & $-0,08$ & $-0,09$ & $-0,08$ & $-0,11$ & $-0,18$ & $-0,31$ & $-0,24$ & $-0,22$ & $-0,31$ & $-0,25$ \\
\hline DEU & $-0,11$ & $-0,14$ & $-0,22$ & $-0,22$ & $-0,19$ & $-0,16$ & $-0,09$ & $-0,03$ & $-0,03$ & $-0,08$ & $-0,03$ & $-0,03$ \\
\hline GRC & $-0,12$ & $-0,13$ & $-0,08$ & $-0,33$ & $-0,20$ & $-0,13$ & $-0,07$ & $-0,06$ & $-0,06$ & $-0,07$ & $-0,07$ & $-0,06$ \\
\hline HUN & $-0,13$ & $-0,15$ & $-0,18$ & $-0,17$ & $-0,10$ & $-0,36$ & $-0,29$ & $-0,32$ & $-0,26$ & $-0,25$ & $-0,30$ & $-0,25$ \\
\hline ITA & $-0,16$ & $-0,15$ & $-0,14$ & $-0,15$ & $-0,07$ & $-0,10$ & $-0,09$ & $-0,07$ & $-0,07$ & $-0,07$ & $-0,08$ & $-0,08$ \\
\hline NLD & $-0,12$ & $-0,11$ & $-0,17$ & $-0,16$ & $-0,24$ & $-0,11$ & $-0,19$ & $-0,13$ & $-0,14$ & $-0,15$ & $-0,14$ & $-0,14$ \\
\hline $\mathrm{POL}$ & $-0,15$ & $-0,16$ & $-0,13$ & $-0,13$ & $-0,18$ & $-0,12$ & $-0,09$ & $-0,10$ & $-0,09$ & $-0,09$ & $-0,10$ & $-0,09$ \\
\hline PRT & $-0,12$ & $-0,11$ & $-0,15$ & $-0,13$ & $-0,06$ & $-0,09$ & $-0,10$ & $-0,05$ & $-0,04$ & $-0,04$ & $-0,05$ & $-0,04$ \\
\hline SVK & $-0,15$ & $-0,15$ & $-0,15$ & $-0,14$ & $-0,08$ & $-0,13$ & $-0,18$ & $-0,17$ & $-0,17$ & $-0,17$ & $-0,17$ & $-0,16$ \\
\hline ESP & $-0,17$ & $-0,19$ & $-0,09$ & $-0,08$ & $-0,07$ & $-0,08$ & $-0,08$ & $-0,06$ & $-0,06$ & $-0,06$ & $-0,06$ & $-0,06$ \\
\hline SWE & $-0,11$ & $-0,08$ & $-0,18$ & $-0,14$ & $-0,08$ & $-0,07$ & $-0,27$ & 0,00 & $-0,25$ & $-0,30$ & 0,00 & $-0,25$ \\
\hline TUR & $-0,15$ & $-0,16$ & $-0,15$ & $-0,13$ & $-0,28$ & $-0,07$ & $-0,14$ & $-0,17$ & $-0,17$ & $-0,16$ & $-0,18$ & $-0,18$ \\
\hline GBR & $-0,17$ & $-0,18$ & $-0,29$ & $-0,10$ & $-0,05$ & $-0,06$ & $-0,24$ & $-0,33$ & $-0,34$ & $-0,31$ & $-0,34$ & $-0,34$ \\
\hline USA & $-2,96$ & $-2,94$ & $-2,85$ & $-2,76$ & $-2,59$ & $-2,32$ & $-2,65$ & $-2,35$ & $-2,50$ & $-2,53$ & $-2,29$ & $-2,50$ \\
\hline (1-EJ) & 3,96 & 3,94 & 3,85 & 3,76 & 3,59 & 3,32 & 3,65 & 3,35 & 3,50 & 3,53 & 3,29 & 3,50 \\
\hline Entropy weights & 0,09 & 0,09 & 0,09 & 0,09 & 0,08 & 0,08 & 0,08 & 0,08 & 0,08 & 0,08 & 0,08 & 0,08 \\
\hline
\end{tabular}

In the Table 1, the main and sub-indicators used for the analysis are seen. In the Table 2, the data for the indicators are given. In the Table 3, enthropy weights of the entrepreneurship indicators are calculated. According to Table 3, the indicators $I_{1}, I_{2}, l_{3}, I_{4}$ have got a weight share of $\% 9$ and $I_{5}, I_{6}, l_{7}, I_{8}, I_{9}, I_{10}, l_{11}, l_{12}$ have got a weight share of \%8. After getting entoropy weights, ranking for the countries are provided by using Maut method. In the Table 4, firstly all of the utility values are calculated for the each indicators shown by $I_{1}, I_{2}, \ldots . . I_{12}$. The prefered country will have the highest total score. 
According to Maut rankings; USA is the best ranked country and Italia is the second one and the worst ranked country is the Slovak Republic. Turkey is in the sixth rank among the 20 OECD countries.

Table 4: Total Utility

\begin{tabular}{|c|c|c|c|c|c|c|c|c|c|c|c|c|c|}
\hline & $\mathrm{I}_{1}$ & $\mathrm{I}_{2}$ & $\mathrm{I}_{3}$ & $I_{4}$ & $I_{5}$ & $I_{6}$ & $\mathrm{I}_{7}$ & $I_{8}$ & $I_{9}$ & $I_{10}$ & $\mathrm{I}_{11}$ & $\mathrm{I}_{12}$ & Total utility \\
\hline AUT & 0,053 & 0,059 & 0,003 & 0,006 & 0,083 & 0,003 & 0,002 & 0,005 & 0,003 & 0,002 & 0,004 & 0,003 & 0,227 \\
\hline BEL & 0,036 & 0,035 & 0,015 & 0,009 & 0,005 & 0,003 & 0,005 & 0,004 & 0,002 & 0,001 & 0,004 & 0,003 & 0,122 \\
\hline CAN & 0,068 & 0,063 & 0,011 & 0,011 & 0,005 & 0,003 & 0,006 & 0,012 & 0,011 & 0,019 & 0,000 & 0,011 & 0,222 \\
\hline CZE & 0,006 & 0,011 & 0,023 & 0,014 & 0,003 & 0,002 & 0,039 & 0,007 & 0,007 & 0,005 & 0,007 & 0,006 & 0,130 \\
\hline DNK & 0,046 & 0,046 & 0,000 & 0,000 & 0,003 & 0,001 & 0,000 & 0,003 & 0,001 & 0,000 & 0,003 & 0,001 & 0,104 \\
\hline FIN & 0,092 & 0,091 & 0,012 & 0,007 & 0,005 & 0,002 & 0,002 & 0,003 & 0,001 & 0,000 & 0,003 & 0,001 & 0,219 \\
\hline FRA & 0,012 & 0,014 & 0,006 & 0,004 & 0,079 & 0,002 & 0,052 & 0,021 & 0,019 & 0,038 & 0,024 & 0,022 & 0,294 \\
\hline DEU & 0,035 & 0,028 & 0,001 & 0,003 & 0,006 & 0,003 & 0,034 & 0,062 & 0,035 & 0,041 & 0,061 & 0,038 & 0,345 \\
\hline GRC & 0,000 & 0,034 & 0,050 & 0,033 & 0,035 & 0,008 & 0,012 & 0,002 & 0,000 & 0,007 & 0,002 & 0,000 & 0,183 \\
\hline HUN & 0,005 & 0,025 & 0,001 & 0,087 & 0,039 & 0,004 & 0,008 & 0,005 & 0,003 & 0,005 & 0,005 & 0,003 & 0,191 \\
\hline ITA & 0,017 & 0,039 & 0,030 & 0,019 & 0,009 & 0,077 & 0,084 & 0,066 & 0,040 & 0,052 & 0,056 & 0,038 & 0,528 \\
\hline NLD & 0,042 & 0,040 & 0,018 & 0,015 & 0,004 & 0,002 & 0,011 & 0,006 & 0,004 & 0,005 & 0,007 & 0,005 & 0,158 \\
\hline $\mathrm{POL}$ & 0,011 & 0,017 & 0,027 & 0,016 & 0,058 & 0,003 & 0,039 & 0,014 & 0,014 & 0,020 & 0,014 & 0,014 & 0,247 \\
\hline PRT & 0,036 & 0,043 & 0,014 & 0,011 & 0,033 & 0,004 & 0,012 & 0,009 & 0,007 & 0,008 & 0,009 & 0,007 & 0,192 \\
\hline SVK & 0,008 & 0,014 & 0,020 & 0,011 & 0,002 & 0,002 & 0,013 & 0,004 & 0,001 & 0,002 & 0,004 & 0,001 & 0,080 \\
\hline ESP & 0,037 & 0,039 & 0,020 & 0,012 & 0,006 & 0,005 & 0,034 & 0,021 & 0,018 & 0,026 & 0,020 & 0,018 & 0,256 \\
\hline SWE & 0,048 & 0,063 & 0,003 & 0,001 & 0,004 & 0,001 & 0,010 & 0,005 & 0,003 & 0,003 & 0,005 & 0,003 & 0,147 \\
\hline TUR & 0,003 & 0,000 & 0,031 & 0,012 & 0,005 & 0,000 & 0,078 & 0,000 & 0,038 & 0,073 & 0,000 & 0,039 & 0,279 \\
\hline GBR & 0,036 & 0,044 & 0,020 & 0,011 & 0,080 & 0,000 & 0,023 & 0,022 & 0,019 & 0,023 & 0,021 & 0,021 & 0,321 \\
\hline USA & 0,056 & 0,058 & 0,089 & 0,006 & 0,000 & 0,000 & 0,058 & 0,078 & 0,081 & 0,079 & 0,076 & 0,081 & 0,661 \\
\hline
\end{tabular}

\section{CONCLUSION}

We measure the entrepreneurship performance of OECD countries by using the Entropy-Maut hybrid model. 20 OECD countries are included in this model because of data limitations related with the mentinoned indicators. The data is covering years 2014-2015. First of all we found the weights of each indicator. Then considering the entropy weights, we ranked OECD countries by using Maut method. As a result, we constracted a new index for entrepreneurship data. According to ranked results; the countries which are in the best ranking according to five main indicators are; USA, Italy, Germany and Great Britain. The countries that have low rankings are Belgium, Denmark and Slovak Republic. Turkey is in the sixth rank among the 20 OECD countries. 


\section{REFERENCES}

Acs ZJ, Audretsch DB, Evans DS 1994 The determinants of variations in self-employment rates across countries and over time. Discussion Paper 871, Centre for Economic Policy Research, London

Audretsch, D. B., Verheul, I., Thurik, A. R., \& Wennekers, S. (Eds.). 2002. Entrepreneurship: Determinants and Policy in a European-US Comparison. Boston and Dordrecht: Kluwer Academic Publishers.

Audretsch, D.B., Fritsch, M., 2002. Growth regimes over time and space. Regional Studies 36, 113-124.

Audretsch, D., Fritsch, M., 2003. Linking entrepreneurship to growth: The case of West Germany. Industry and Innovation 10, 65-73.

Audretsch, D.B., 2007. Entrepreneurship capital and economic growth. Oxford Review of Economic Policy 23, 63-78.

Blanchflower DG 2000. Self-employment in OECD countries. Labor Econ 7(5):471-505

Blau D. 1987 A time-series analysis of self-employment in the United States. J Polit Econ 95(3):445-467

Clausius, R. , (1867)"The Mechanical Theory of Heat - with its Applications to the Steam Engine and to Physical Properties of Bodies". London

Decker, R., Haltiwanger, J., Jarmin, R., Miranda, J., 2014. The role of entrepreneurship in US job creation and economic dynamism. The Journal of Economic Perspectives 28(3), 3-24.

Elert, N., Henrekson, M. , Stenkula , M. 2017. Institutional Reform for Innovation and Entrepreneurship: An Agenda for Europe, IFN Working Paper No. 1150.

Grilo I, Thurik AR. 2005 . Latent and actual entrepreneurship in Europe and the US: some recent developments. Int Entrep Manag J 1(4):441-459

Grilo I, Irigoyen JM. 2006. Entrepreneurship in the EU: to wish and not to be. Small Bus Econ 26(4):305-318

Keeney, R. L. and Raiffa, H. (1976). Decisions with Multiple Objectives: Preferences and

Value Tradeoffs. Wiley,New York. Reprinted, Cambridge Univ. Press, New York (1993). MR0449476

Saaty, T.L. The Analytic Hierarchy Process; McGraw-Hill: NewYork, NY, USA, 1980.

Shannon, C.E. "A mathematical theory of communication". Bell Syst. Tech. J. 1948, 27,

379-423

Salman, D.M., Badr, K., 2011. Linking Entrepreneurship and Total Factor Productivity What are the Economic Setting Required? Paper prepared for the 17th annual international conference of the ERF.

S.D. Pohekar, M. Ramachandran Application of multi-criteria decision making to sustainable energy planning-A review Birla Institute of Technology and Science (BITS), Pilani 333 031, India

Van Stel, A., Carree, M., Thurik, R., 2005. The effect of entrepreneurial activity on national economic growth. Small business economics 24 , 311-321.

Vázquez, E., Gómes, S., Vieira, E., 2010. Entrepreneurship and economic growth in Spanish and Portuguese Regions. Regional and Sectoral Economics Studies 110-126.

Wennekers, S., Van Wennekers, A., Thurik, R., Reynolds, P., 2005. Nascent entrepreneurship and the level of economic development. Small business economics 24, 293-309.

Wennekers ARM .2006. Entrepreneurship at country level: economic and non-economic determinants, PhD thesis, Erasmus Research Institute of Management (ERIM), Rotterdam

Wu, Jian-Zhang, and Qiang Zhang. "Multicriteria decision making method based on intuitionistic fuzzy weighted entropy." Expert Systems with Applications 38.1 (2011): 916-922.

Zhang, H., Gu, C. L., Gu, L. W., \& Zhang, Y. (2011). The evaluation of tourism destination competitiveness by TOPSIS \& information entropyA case in the Yangtze River Delta of China. Tourism Management, 32(2), 443-451. 